\title{
SOCIALINIO DARBUOTOJO PSICHOSOCIALINE PAGALBA KRŪTIES VĖŽIU SERGANČIOMS MOTERIMS
}

\author{
Virginija Kondratavičienė, Laima Vendzelienė \\ Kauno kolegija
}

Raktažodžiai: socialinis darbuotojas, krūties věžiu sergančios moterys, psichosocialinè pagalba.

\section{Santrauka}

Krūties vėžys - dažniausia moterų onkologinè liga. Susirgusi krūties vėžiu moteris išgyvena kelias šios ligos fazes, kurių kiekvienoje patiria skirtingas psichosocialines problemas ir rūpesčius. Moterys, sergančios krūties vėžiu, išgyvena šoko būseną, jaučiasi bejëgiškos, praradusios kontrolę, būna piktos. Susirgus dažnai pasikeičia šeiminiai santykiai, nuo ligonès nutolsta draugai ir buvę artimi žmonès. Labai dažnai onkologiniai ligoniai puola ị neviltị, nebetiki savo jègomis, pasijunta nevisaverčiais, jaučiasi našta savo šeimai ir artimiesiems. Šios fazès priklauso nuo ligos eigos bei paskirto gydymo - pradedant ligos diagnoze, gydymu, jo baigimu, grị̌imu ị ịprastini gyvenimą, ligos pasikartojimu ar perejjimu prie paliatyviosios priežiūros. Svarbu ịvertinti socialinių darbuotojų pagalbą moterims, kurios susiduria su psichosocialinèmis problemomis. Tyrimo metu atsiskleidè, kad dažnai krūties vėžiu sergančias moteris kamuoja ịvairios psichosocialinès problemos. Tai nutrūkę ar susilpnėję ryšiai su artimaisiais, draugais, pyktis, stresas, nerimas dèl ateities. Tyrime dalyvavusios moterys teigè, kad socialinio darbuotojo teikiama psichosocialinè pagalba joms labai reikalinga pagerinti psichologini prisitaikymą prie pasikeitusio gyvenimo bei stiprinti socialinius ryšius. Informantès akcentavo intensyvios krizių ịveikimo pagalbos reikalingumą, tarpusavio savipagalbos grupių organizavimą ir igalinimą jose dalyvauti.

\section{Ivadas}

Lietuvoje piktybiniai navikai yra antra pagal dažnị žmonių mirtingumo priežastis. Kaip ir visame pasaulyje, krūties věžys yra dažniausia piktybinè moterų liga [3]. Remiantis preliminariais Nacionalinio vėžio instituto Véžio registro duomenimis, Lietuvoje nustatyti 1526 krūties vèžio atvejai
(18 proc. visų moterų piktybinių navikų), Kasmet dèl šios ligos miršta per 500 moterų. Lietuvoje penkerių metų išgyvenamumo rodiklis susirgus krūties vèžiu nuo 2000 metų padidejo beveik 10 proc. ir $2015 \mathrm{~m}$. siekè 77 proc., tačiau ir toliau išlieka vienas prastesnių Europoje. Nors mamografinès patikros programa Lietuvoje vykdoma jau daugiau nei 15 metų, vis dar daug krūties vėžio atvejų nustatoma per vèlai - net trečdalis naujų krūties vėžio atvejų diagnozuojami pažengusios stadijos [3]. Tai viena aktualiausių moterų sveikatos problemų pasaulyje ir viena dažniausių moterų onkologinių ligų Lietuvoje. Remiantis Lietuvos vėžio registro duomenimis, Lietuvoje kiekvienais metais daugejja krūties věžiu susergančių moterų, o mirčių skaičius išlieka didžiausias, palyginti su kitos lokalizacijos piktybiniais navikais.

Krūties vėžio diagnozė moterị veikia ne tik fiziškai, bet ir emociškai bei psichologiškai, nes tai labai grèsminga liga ir didelis psichologinis išbandymas, keliantis psichosocialiniu sunkumų. Pakitusi organizmo būklè, kompleksinis chirurginis, spindulinis, hormoninis gydymas, chemoterapija veikia moters fizinị, socialinị, funkcinị ir emocinị būvị. Sunkumai, su kuriais susiduria dauguma věžiu sergančių moterų, yra netikrumas, vaidmenų šeimoje ir darbe perkūrimas, finansiniai sunkumai, trumpalaikè ir ilgalaikè fizinè negalia, vėžio ligos pasikartojimo tikimybè, nepriklausomumo, autonomiškumo kūrimas iš naujo, sutrikęs seksualinis gyvenimas ir vaisingumas, kūno pokyčiai [4]. Onkologinè liga sukelia ne tik fizines kančias, bet turi neigiamą ittaką ir psichosocialinei moters būklei. Socialinis darbuotojas, teikdamas psichosocialinę pagalbą, siekia gerinti sergančių moterų gyvenimo kokybę bei psichologini prisitaikymą.

Pasaulio sveikatos organizacija deklaruoja, kad nesant psichinès sveikatos, negalima visapusè sveikata. Perèjimas nuo biomedicininio modelio prie išsamaus psichosocialinio priežiūros modelio tebèra didelis iššūkis. Apie psichosocialines onkologinių ligonių problemas ir psichosocialinę pagalbą šiai tikslinei grupei savo darbuose rašè labai daug mokslininkų, tarp kurių žinomiausia Bultz (2016) [5]. Psi- 
chosocialinėmis paslaugomis, jų specifika domėjosi $\mathrm{M}$. Loscalzo (2016) [6].

Tyrimo tikslas - nustatyti socialinio darbuotojo veiklą, teikiant psichosocialinę pagalbą krūties vėžiu sergančioms moterims.

\section{Tyrimo medžiaga ir metodai}

Tyrimui atlikti naudojama mokslinès literatūros analizè ir kokybinis tyrimo metodas, pusiau struktūruotas interviu. Tyrime dalyvavo penkios krūties vėžiu sergančios moterys, gyvenančios įvairiuose Lietuvos miestuose ir miesteliuose. Informančių amžius nuo 38 iki 73 metų. Moterys buvo supažindintos su bendra tyrimo informacija, uždaviniais, tikslu, konfidencialumo politika bei galimybe bet kada nutraukti dalyvavimą tyrime. Tyrimui atlikti informantems buvo užduota 15 klausimų. Kai kurie klausimai buvo neplanuoti ir užduoti interviu eigoje, siekiant ịsigilinti ir išsiaiškinti krūties věžiu sergančių moterų patiriamus psichosocialinius sunkumus ir socialinio darbuotojo veiklą, teikiant psichosocialinę pagalbą. Interviu pradžioje buvo užduodami klausimai, susiję su moterų charakteristika. Tolesnèje interviu eigoje buvo užduodami klausimai, kurių pagalba siekta nustatyti socialinio darbuotojo veiklą, teikiant psichosocialinę pagalbą moterims, sergančioms krūties věžiu.

\section{Tyrimo rezultatai}

Išgirdusios krūties véžio diagnozę, dauguma moterų patiria psichologinę krizę, kurią lydi tokie jausmai: kaltè, gèda, nerimas, depresija, pasimetimas. Moterys patiria stiprių emocinių išgyvenimų, kurie dažniausiai tęsiasi ir po to, kai praeina pirminis šokas. Neretai sergančiosioms sunku pripažinti ligą ir susitaikyti su diagnoze dèl visuomenèje paplitusio baimingo požiūrio ị vėžį. Sudètingas gydymas, jo šalutiniai reiškiniai, būsima operacija ir kiti pokyčiai priverčia susitaikyti su esama padètimi. Krūties vèžio gydymas, stiprūs emociniai išgyvenimai moteris labai išsekina fiziškai ir emociškai.

Gavus informančiu atsakymus į užduotą klausimą apie jų reakciją i ligą, paaiškejjo, kad dažniausiai moterys stengési paneigti esamą situaciją: ,,negalëjau patikèti, nesąmoné kažkokia, suklydot sakau, man nieks neskauda, aš gerai jaučiuosi..." (Laura). Kaip atsakas ị traumuojančios žinios poveiki kilusi apatija ir neigimas paprastai tęsiasi keletą pirmųjų dienų, sužinojus diagnozę [1]. Viena informantè teigè, kad jai nustatyta diagnoze negalèjo patikèti iš pirmo karto, i̊sitikino tik dar kartą pakartojusi tyrimus: ,, $<\ldots>i$ is karto nepatikejau, net minties tokios neprileidau, <...> susiradau kita gydytoja ir pakartojau tyrimus, bet deja, jie buvo tokie patys... " (Lina). Viena tyrimo dalyvè teigè, kad sužinojus

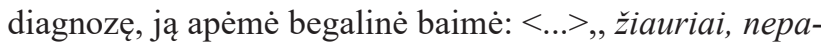

menu kaip iš kabineto išejjau ir kaip namo grįžau, <..> negalejau nustot verkti ir taip koki mènesi..." (Daina). Sužinojus diagnozę, neigimą pamažu pakeičia stipraus nerimo ir depresijos būsena, kuri trunka maždaug dvi savaites [1]. Tyrimai ir klinikiniai stebejimai rodo, kad maždaug penktadaliui pacienčių būdingos aštrios gedejimą primenančios emocinès reakcijos.

Interviu metu paaiškèjo ir savęs kaltinimo užuominų. Viena tyrimo dalyvè teigè: $<\ldots .>$, ,kodèl man, ko gero matyt gyvenime kažka ne taip darau ir dievulis baudžia mane atsiusdamas tokia liga... " (Elena).

Tyrimo metu paaiškejjo, kad vienas iš didžiausių sunkumų tyrimų dalyvèms - tai susitaikyti su liga, nes išgirdusios diagnozę jautėsi sugniuždytos, išsigandusios dẻl nežinomos ateities ir sugriuvusių gyvenimo planų: , , ...> kito kelio nèra, $<\ldots>$ reikia gydytis, büti stipriai dèl vaiku ir tikètis, kad pasveiksiu..." (Lina).

Kiekvienos tyrimo dalyvès reakcija ị ligą yra individuali ir tai turi įtakos jos gyvenimo kokybei. Apklaustos moterys ligą išgyvena skirtingai, tačiau išbandymai, kuriuos tenka ịveikti išgirdus diagnozę, bendri visoms tyrimo dalyvèms. Šiame etape moterims tenka priimti kai kurių funkcijų netekimą, igyti naujų ịgūdžių ir persiorientuoti ị kitokią kasdieninę rutiną tam, kad galètų kontroliuoti ligos simptomus ir iveikti sunkų gydymą. ,Nurimau ir supratau, kad čia nèra pats baisiausias dalykas gyvenime, išsikapstysiu..." (Laura).

Rizika sirgti krūties vèžiu padidèja vyresnio amžiaus moterims. Krūties véžiui atsirasti didžiausios įtakos turi paveldimumas, jonizuojamoji spinduliuotè, estrogenų poveikis. Palanki krūties véžiui sąlyga yra rūkymas, neigiamų emocijų slopinimas bei beviltiškumo jausmas streso atvejais. Rizika susirgti krūties vẻžiu didèja, jei ši liga kartojasi giminèje. Atlikus tyrimą paaiškèjo, kad daugumai apklaustujjų ligą sukèlè genetiniai veiksniai, kurių poveikio pats žmogus negali kontroliuoti. ,Paveldèjau, mano tèvukas miré nuo vėžio, brolio dukra mirè nuo vėžio.. <...> vis tik dariausi genetini tyrima, tai patvirtino, kad paveldimas". (Nida). Dvi informantès teigè, kad ligą paskatino dideli emociniai išgyvenimai, didelis stresas. „Mano gydytoja įtaria, kad mano patirtas stresas ịtakos turejo... < ..> sünus pakliuvo i avarija, buvo stuburo trauma, <...> metus iš proto krausčiausi, negalejau nei valgyt nei miegot... " (Laura). Vienos tyrimo dalyvès teigimu, jai krūties věži paskatino ginekologinè operacija. „Gydytojų nuomone, piktybinį navika atsirasti paskatino man daryta ginekologinè operacija, kuri sutrikdè hormonu veikla“ (Lina).

Vèžio informacijos centro (2018) duomenimis, krūties vèžio atsiradimo priežastys iki galo dar nèra išsiaiškintos. Vyresnių moterų rizika susirgti yra didesnè, jaunesnių - mažesnè. Vidutiniškai daugiausia naujų krūties vėžio atvejų 


\section{8}

nustatoma moterims, turinčioms daugiau nei 50 metų [7].

Remiantis tyrimo rezultatais, išsiaiškinta, kad krūties vèžiu sergančių moterų gyvenimo kokybei labiausiai kenkia ir įtakos turi nuovargis, nemiga, nerimas, skausmas, apetito stoka. Problemų sukelia ir fizinis rankos funkcionavimas rankos arba peties skausmai, rankos patinimai ir sunkumai kilnoti arba judinti ranką. Analizuojant rezultatus, pastebėta, kad labiausiai liga paveikè pacienčiu įtemptą veiklą ir ilgus pasivaikščiojimus. „Stengiausi daug vaikščioti, bet nueidavau koki kilometra ir baigdavosi jegos, jaučiausi kaip kokia išsunkta citrina" (Daina).

Tyrimo metu nustatytos penkios moterų patiriamų psichosocialinių problemų subkategorijos.

Pirmoji subkategorija - nuovargis. Dažniausiai jis vargina užsiimant fizine veikla, tokia kaip namų ruoša, išejimas ị lauką pasivaikščioti. Nuovargis kankina dèl ịvairių patiriamų skausmų. Remiantis tyrimo dalyvių atsakymais, nustatyta, kad visas moteris kamuoja nuovargis dar ir dèl ilgo intensyvaus gydymo.

Antroji subkategorija yra miego sutrikimai (skausmas). Šiuos sutrikimus patyrẻ keletas tyrimo dalyvių. Miego sutrikimai yra vienas iš specifinių véžio simptomų, jie turi labai didelès reikšmès sergančių moterų gyvenimo kokybei. Nuolatinè nemiga labai išvargina ir kelia daug problemų, nes gydymo metu poilsis sergančiosioms yra ypač svarbus. Miego sutrikimų priežastis gali būti ir nuolatinis nerimas dèl ligos, dẻl skausmo [8]. Moterims po operacijos būna skausminga pažasties sritis, krūties žaizda ir ranka, ypač kai ją norima pakelti ar pasukti. Kartais moterys po krūties operacijos negali laisvai judinti rankos, jaučia peties sustingimą. Sustingimas stipriau pasireiškia po mastektomijos. Kartais dèl nervų pažeidimo operacijos metu sutrinka peties audinių jautrumas, tada jaučiamas jų tirpimas [18]. Kaip teigia viena tyrimo dalyve,,$<\ldots>$ nepamiegu, tirpsta, skauda ranka, vis nerandu tinkamos pozicijos atsigulti, kad neskaudetu “ (Daina). Pamažu šie simptomai daugumai moterų išnyksta, tačiau kai kurioms, ypač toms, kurioms buvo pašalinti ir pažasties limfmazgiai, gali išlikti.

Trečioji subkategorija - nuotaiku kaita. Ją patyrẻ visos informantès. Viena įvardijo nuotaikų kaitos priežastị: ,, būnu geros nuotaikos, bet užtenka kam nors padejuoti, $<\ldots>$ kaip tu tokia jauna dar ir susirgai $<\ldots>$ tai toks siutas paimdavo, ilgai negaledavau nurimti “ (Laura).

Ketvirtoji subkategorija - stresas. Galima teigti, kad visos tyrimo dalyvès patyrè stresą, baimę ir nerimą. Tai silpnina imunitetą ir trukdo gijimo procesui.

Penktoji subkategorija - nerimas ir baimè. Gana dažnai moterys, sergančios krūties vėžiu, patiria nuolatinę baimę [9]. Žmogui baimẻ kyla, susidūrus su pavojumi. Baimei būdinga itampa, susijaudinimas, pakitęs suvokimas. Didelè baimè mažina žmogaus veiklumą, gebèjimą prisitaikyti prie naujų, pasikeitusių gyvenimo sąlygų [10]. Viena tyrimo dalyvė teigè: „, nerimauju ir bijau prieš kiekviena patikrinima, bijau kad vèl ko nerastų..." (Daina).

Toliau analizuojant krūties vèžiu sergančių moterų socialinị gyvenimą ir ligos poveikị socialiniam tinklui, bendravimui, išryškejjo informančių bendravimo su draugais bei artimaisiais pokyčiai. Tokius pokyčius dažnai lemia moteru noras atsiriboti, vengimas bendrauti.

Tyrimo rezultatai išryškino tris kategorijas, kurios apibūdina tyrimo dalyvių santykị su joms artima aplinka, ryšius su draugais ir kolegomis darbe. Gauti atsakymai parodè, kad daugumos santykiai su artimaisiais yra geri, pastovūs ryšiai, tik viena informante teigè, kad nutrūko ryšiai su seserimi: ,${ }<\ldots>$ su seserimi susipykau, nebebendraujam kai susirgau,

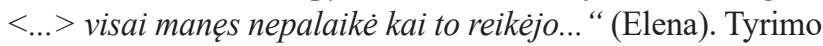
metu paaiškejo, kad neigiamos emocijos dažnai priverčia moteris užsisklęsti, atstumti artimus žmones ir apriboti ar nutraukti socialinius ryšius: „, $<>>$ keletas draugu iškart atsisijojo, tiesiog aš jaučiau, kad nebenoriu su jais palaikyti tolimesnio ryšio..." (Lina).

Kaltè, pyktis, gèda, baimè ir nusivylimas, pasireikšdami dideliu intensyvumu, blogina paciento gyvenimo kokybę, kenkia gydymui bei tarpasmeniniams santykiams [11]. Apibendrinus galima teigti, kad moterys patiria psichosocialiniu problemų. Tyrimo dalyvių šeimos nariai taip pat susiduria su emociniu distresu. Moterų būklè turi įtakos šeimos narių psichinei sveikatai ir emocinei gerovei: , $<\ldots>$ tik dar labiau sustiprejo, tapome tarsi vienas kumštis, <... man atrodo, kad vyras išgyvena dar labiau nei aš..." (Lina).

Pasak I. Yalom (2016), jo dešimt metų stebèti vèžiu sergantys pacientai, užuot pasidavę bukinančiai nevilčiai, smarkiai pasikeitè i gera, iš naujo peržiūrẻjo savo gyvenimo vertybes ir atsisake to, kas nereikšminga. Žmonès ịgijo jẻgu atsisakyti to, ko iš tikrujų nenori, nuoširdžiau bendravo su tais, kuriuos myli, labiau džiaugèsi gamta: metų laikų kaita, gamtos grožiu [12].

Tyrimas parodè, kad visos moterys skaudžiai išgyvena savo kūno pokyčius, atsiradusius dèl krūties vėžio. Kovojančios su krūties vėžio padariniais, jos ima vengti intymumo, rengiasi vienos ar tamsoje, dažnais atvejais net vengia maudytis: ,, _..> pašalino man viena krūtí, jaučiuosi nepilnavertè, gédinuos nusirengti $<\ldots>$ “ (Lina). Véžys, ardantis moters kūną, yra ypač stipraus streso šaltinis. Dvi moterys labai sunkiai išgyveno plaukų netekimą: $<\ldots>$ nuslinko plaukai, iškrito blakstienos, antakiai, buvau tokia baisi... <..> kaukiau viena užsidarius kambary..." (Laura).

Krūties pašalinimas sukelia nerimą, baimę, nepasitikèjimą savimi. Moterims sunku priimti kūno pokyčius, kuriuos sukelia liga. Pradedama neigiamai žiūrèti ị savo kūną. Nors 
daugumai informančių sunku susitaikyti su išvaizdos pokyčiais po operacijos, dalis ju jaučia teigiamas emocijas dèl pašalinto auglio: , < ..> krūtị teko pašalinti, per didelis auglys buvo, bet nesijaudinu del to, svarbu, kad jo nebera... "(Nida).

Trys tyrimo dalyvès neteko svorio ir apetito: ,, <..> per tris mènesius netekau $25 \mathrm{~kg}$. svorio, buvau vaikščiojantis skeletas" (Laura).

Visos tyrimo dalyvès pabrèžè, kad keitèsi požiūris ị vertybes, imta daugiau vertinti kiekviena gyvenimo minuté: „<...> pasikeitè prioritetai visiškai, darbas liko paskutineje vietoje, dabar visas dèmesys šeimai... “(Daina). ,, < ..> kai pagalvoju, dabar net juokas ima, kiek reikšmès skirdavau anksčiau nereikšmingiems dalykams... "(Laura).

Tyrimas atskleidè, kad jaunesnès informantès labiau emociškai pažeidžiamos. Tai dažniausiai susiję su ateities perspektyvų neturejimu, neigiamu savo išvaizdos vertinimu. Jaunesnès informantès bijo netekti plaukų dèl chemoterapijos, krūties pašalinimo: ,, $<\ldots>$ nekenčiau net pažiūrèti $i$ save" (Daina).

Gyvenimo kokybès tyrimai, susiję su sveikata susirgus krūties vèžiu, yra ypač svarbūs ir turi būti atliekami keletą kartų, nes tik tada jie bus tikslesni ir naudingesni, prognozuojant moterų darbingumo lygị ir išgyvenimo trukmę, nustatant gydymo efektyvumą [13].

Apibendrinant galima teigti, jog ne tik moters sveikata, bet ir požiūris i ją yra svarbūs gyvenimo kokybès elementai. Sunki liga neišvengiamai paliečia visas moters gyvenimo sritis: fizinę, psichologinę, socialinę ir dvasinę. Sveikatos problemos priverčia moterị iš naujo įvertinti gyvenimo vertybes ir kokybės sampratą iš naujų pozicijų. Pasak minètų informančių, šis vertinimas - labai individualus suvokimas, kuriam dažnai įtakos turi asmens vidiniai ištekliai.

Pagrindinè onkologijoje dirbančio socialinio darbuotojo misija yra meistriškai teikti psichosocialinę pagalbą krūties vėžiu sergančiomis moterimis bei jų šeimoms [14]. Jis teikia psichosocialinę paramą, kad pagerintų moterų sveikatą bei funkcionavimą individualiame, šeimos, grupių ir visuomenès gyvenime, paveiktame véžio ligos.

Šiuo tyrimu nustatyta, kad informantès naudojosi socialinio darbuotojo paslaugomis. Apklausos metu informantès teigé, kad joms labai buvo reikalingos konsultavimo ir informavimo paslaugos. Viena informantė pažymėjo, jog socialinis darbuotojas galètų konsultuoti jos artimuosius: „<...>netgi ne man, o mano artimiesiems, vyrui ypač bütu naudinga tokia pagalba, jis žmogus jaudinasi labiau už mane, nori man padeti, bet nežino kaip... " (Laura). Kelioms informantems buvo suteikta informacija apie kompensacinę techniką (specialias liemenèles, krūties protezus): ,, <..> patare kokios firmos liemenèlés ir protezai yra patogiausi “
(Lina). Kitos apklausos dalyvès teigè, kad joms labai pagelbejjo pokalbiai su socialiniu darbuotoju, džiaugèsi, kad turèjo kam išsipasakoti, buvo išklausytos ir suprastos, jaute emocinę paramą. Kitos informantès apgailestavo, kad vis dèlto trūko joms savalaikès informacijos ir konsultacijos dèl kompensacinès technikos įsigijimo galimybès, Informantès teigè, kad joms šiuo metu reikalinga speciali liemenèlè po krūties operacijos.

Visos tyrimo dalyvès mano, kad socialinio darbuotojo teikiama psichosocialinè pagalba labai svarbi. Svarbiausia - emocinè parama stresinèse situacijose. Pacientu psichosocialinių poreikių, pagalbos ligoniams ir jų šeimoms organizavimą reglamentuoja LR teisès aktai $[15,19]$, kuriuose nurodoma, jog socialiniai darbuotojai tarpininkauja tarp sveikatos priežiūros personalo ir paciento, teikia informaciją, informuoja paciento artimuosius apie pagalbos poreiki ir priemones, konsultuoja, koordinuoja santykius su šeima, padeda spręsti sergančiojo socialines problemas ir bendradarbiauja su medikais.

Savipagalbos grupės yra vienas plačiausiai naudojamų psichosocialinès intervencijos metodų. Šis metodas remiasi idejja, kad visi individai turi vidinių išteklių, kuriuos galima sužadinti susidūrus su stresoriumi [16]. Savipagalba - tai mokejjimas susitelkti ir panaudoti savo jègas palaipsniui keisti savo gyvenimą. Savipagalbos metu žmonès stengiasi atpažinti ir patirti savo pačių skausmą ir naujai suvokia atsakomybę už savo jausmus. Tai abipusio pasitikèjimo erdvė, kurioje moterims sudarytos galimybès keistis. Grupès nariai dirba kartu dalindamiesi problemomis, keisdami požiūrị ị tam tikrus dalykus, ieškodami naujų ligos įveikos būdų, tokios grupès - tai ịvairių problemų sprendimo būdas, pagrịstas asmeninès patirties dalijimusi [17].

Tyrimu nustatyta, kad šis metodas mažina streso simptomus, gerina nuotaiką ir skausmo supratimą moterims, sergančioms krūties vėžiu. Tai patvirtina informantès žodžiai: „<...> esu uždaro būdo, nemégstu savo problemu užkrauti kitiems, $<\ldots>$ be to mano isitikinimu, žmogus, kuris nera to išgyvenęs, tavęs nesupras, tai man savipagalbos grupe buvo kaip išganymas, tu gali pasidalinti savo išgyvenimais su tuo kas yra išgyvenęs ta pati, $<\ldots>$ be galo naudinga patirtis “(Lina).

Apibendrinant tyrimo rezultatus galima teigti, kad dažniausiai krūties vėžiu serga vidutinio ir vyresnio amžiaus moterys. Informantès, sužinojusios kad serga krūties vėžiu, jaučiasi sukrèstos ir negali apsiprasti su mintimi, kad jų gyvenimas pasikeitè. Moterys, susirgusios krūties vėžiu, teigè, kad jas kamuoja įvairios psichosocialinès problemos, tokios kaip nutrūkę ar susilpnèję ryšiai su artimaisiais, draugais ar kolegomis darbe, kamuoja pyktis, esamos situacijos neigimas, stresas, nemiga, baimès jausmas, nerimas dèl ateities ir 
artimujų. Tyrimo metu atsiskleide, kad dažnai krūties vėžiu sergančios moterys atsiriboja nuo aplinkos ir taip silpnina savo socialinius ryšius. Informantès teigè, kad dažnai susiduria su finansinemis problemomis, kadangi vaistai labai brangūs, o ir kelionès ị gydymo įstaigą atima nemažai pinigų. Gydymo įstaigoje moterys naudojosi socialinio darbuotojo paslaugomis, naudojosi ir grịžusios į namus. Tyrimo metu išryškejjo, kad visos socialinio darbuotojo teikiamos socialinès paslaugos moterims, sergančioms krūties vėžiu, yra skirtingai ir individualiai svarbios bei reikalingos. Informantės teigè, kad dažniausiai gavo informavimo, konsultavimo paslaugas. Tyrime nustatyta, kad krūties vėžiu sergančioms moterims ir jų artimiesiems šiuo metu labiausiai reikalingos informavimo, konsultavimo, tarpininkavimo ir atstovavimo socialinès paslaugos bendradarbiaujant su gydytojais, intensyvi krizių iveikimo pagalba, tarpusavio savipagalbos grupių organizavimas ir igalinimas jose dalyvauti.

\section{Išvados}

1. Moterys, sergančios krūties vèžiu, patiria psichologinių sunkumų ir socialinių problemų, šeiminių santykių pasikeitimą, draugų nutolimą, todèl socialinių darbuotojų teikiama psichosocialine pagalba yra svarbi sveikimo dalis. Socialinis darbuotojas yra tarsi atspirties taškas, norint susivokti bei prisitaikyti prie gyvenimo pokyčių. Šiuo atveju socialinis darbuotojas teikia specialiąsias socialines paslaugas, kurių pagrindą sudaro psichosocialinė pagalba, intensyvių krizių ịveikimo pagalba ir bendrąsias socialines paslaugas - informavimo, konsultavimo, tarpininkavimo ir atstovavimo. Labai svarbus socialinio darbuotojo pagalbos būdas moterims, sergančioms krūties vèžiu, yra savipagalbos grupių kūrimas, bendradarbiavimas ir veiklų koordinavimas tarp kitų institucijų, teikiančių socialines paslaugas.

2. Atlikto tyrimo duomenys leidžia teigti, kad socialinio darbuotojo veikla teikiant psichosocialinę pagalbą moterims, sergančioms krūties vèžiu ir jų šeimos nariams yra labai svarbi ir reikalinga tiek gydymo įstaigoje, tiek grį̌us į namus, ypač organizuojant intensyvią krizių įveikimo pagalbą, tarpusavio savipagalbos grupes ir skatinant jose dalyvauti. Tyrime išryškejjo, kad ne visos informantės žinojo, jog gali gauti socialinio darbuotojo teikiamą psichosocialinę pagalbą. Visos informantès teigè, kad socialinio darbuotojo teikiama psichosocialinè pagalba joms labai reikalinga, kad pagerintų sergančiujų psichologinį prisitaikymą prie pasikeitusio gyvenimo,stiprintų moterų bendravimą ir jų socialinius ryšius.

\section{Literatūra}

1. Žemaitienė N., Bulotaitė L., Jusienè R., Veryga A. Sveikatos psichologija. Vilnius: Tyto alba, 2011.
2. Šarakauskienė L. Vėžys - nebijoti, o nugalèti. Kaunas: Margažiedis, 2003.

3. Pasaulinę kovos su věžiu dieną - Lietuvos onkologijos apžvalga: iššūkiai laimèjimų netemdo. Nacionalinis véžio institutas, 2021. https://www.nvi.lt/news/502/72/Pasauline-kovos-su-veziudiena-Lietuvos-onkologijos-apzvalga-issukiai-laimejimunetemdo/

4. Paukštytė R. Krūties véžiu sergančių moterų gyvenimo kokybès ir taikomo gydymo metodo ryšys. Visuomenès sveikata, 2015(1 priedas):90-95.

5. Bultz BD. Cancer Care and the Role of Psychosocial Oncology. Where are We and Where are We Going? Asia Pac J Oncol Nurs 2016; 3(2):118-120. 6. Loscalzo MJ. Handbook of Oncology Social Work: Psychosocial Care for People with Cancer. Psycho-Oncology 2016; 25(3):259-360.

https://doi.org/10.1002/pon.4101

7. Nacionalinis věžio institutas. https://www.nvi.lt/ tipai-ir-stadijos/

8. Ivanauskienė V., Liobikaite Ž. Praktinis igalinimo strategijų taikymas dirbant su moterimi - motina „Šeimos užuovejos" programoje. Socialinis darbas, 2004: 3(2): 35.

9. Holland J, Rowland J. Handbook for psycho-oncology. Oxford University Press 1989.

10. Antinienė D., Ausmanienė N., Jakštys J. ir kt. Psichologija studentui. Kaunas: Technologija, 2000.

11. Salmon P. Psychology of medicine and surgery. Wiley: The University of Liverpool, 2000.

12. Yalom I. Žiūrèti ị saulę: Kaip ịveikti mirties baimę. Vilnius: Vaga, 2016.

13. Skvarciany Z., Juocevičius A., Raistenskis J., Povilaitienẻ R. Sergančiujų krūties ir gimdos kaklelio vèžiu gyvenimo kokybẻ pirmaisiais metais po diagnozės nustatymo. Gerontologija , 2011; 12(4): 230-234.

14. Scope of Practice in Oncology Social Work. Association of oncology social work. https://aosw.org/publications-media/ scope-of-practice/

15. Lietuvos Respublikos socialinès apsaugos ir darbo ministro $2006 \mathrm{~m}$. balandžio 5 d. ịsakymas Nr. A1-93 Dèl socialinių paslaugų katalogo patvirtinimo. Galiojanti redakcija 2019-05-24. https://e-seimas.lrs.lt/portal/legalAct/lt/TAD/5e69c2307d911 1e98a8298567570d639

16. Bulotaitė L, Kondrašovienė L, Rimkutè J, Vaitiekus E. Sergančiujų priklausomybès ligomis socialinè integracija: veiksniai ir priemonės. Mokymo programų ciklas specialistams. Kaunas, 2008.

17. Kočiūnas R. Psichoterapinės grupės: teorija ir praktika. Vilnius: VU leidykla, 1998.

18. Gyvenimas su vėžiu. Nacionalinis vėžio institutas. https://www. nvi.lt/gyvenimas-su-veziu/

19. Lietuvos Respublikos sveikatos apsaugos ministro ir Lietuvos Respublikos socialinès apsaugos ir darbo ministro $2019 \mathrm{~m}$. rugsèjo 16 d. įsakymas Nr. V-1065/A1-529 Dèl sveikatos priežiūros ịstaigų socialinių darbuotojų veiklos sveikatos priežiūros 
įstaigose nuostatų patvirtinimo. https://e-seimas.lrs.lt/portal/ legalAct/1t/TAD/46acba91d9d41 1e9a85be81119c7a8fa

\section{ACTIVITIES OF SOCIAL WORKERS PROVIDING PSYCHOSOCIAL SUPPORT TO WOMEN WITH BREAST CANCER}

\section{Kondratavičienė, L. Vendzelienė}

Keywords: breast cancer, psychosocial support, work of a social worker.

Summary

Breast cancer is the most common oncological disorder among women. A woman with breast cancer goes through several phases of the disease, in each of which she faces various psychosocial problems and worries. Affected women can experience a state of shock, feel helpless, angry and a loss of control. Additionally, the illness often changes the relationships of the patient - family, friends and the people that are considered close will start to become distant. It is frequent that oncology patients fall into despair, no longer believing in their strength, feel inferior and as a burden to their family and friends. The course of these phases depends on the progression of the disease and the treatment prescribed - starting with the diagnosis of the disease, start and end of treatment, the return to normal life, recurrence of the disease or the transition to palliative care. Thus, it is important to evaluate the work of social workers for the women who face these psychosocial problems. The study revealed that women with breast cancer often suffer from various psychosocial problems, such as broken or weakened relationships with relatives, friends, they are tormented by anger, stress, anxiety about the future. The women who took part in the study stated that the psychosocial help provided by a social worker was very necessary for them to improve the psychological adaptation of sick women to a changed life and to strengthen women's social ties. The informants emphasized the need for intensive crisis management assistance, the organization of mutual self-help groups and the empowerment to participate in them.

Correspondence to: virginija.kondrataviciene@go.kauko.lt

Gauta 2021-10-28 